\title{
THE ART OF THE SHILL: INTERNET PRODUCT CONSUMPTION FOR SAVVY
} CONSUMERS

\author{
Brian J. Stevens, Robert Morris University, brianstevens13@gmail.com \\ Jennifer Harlan, Robert Morris University,jharlan15@yahoo.com \\ David B. Scibelli, Robert Morris University, davidscibelli@yahoo.com
}

\begin{abstract}
In expansion of the Internet marketplace, consumers are inundated with products targeted to their personal interests. As consumers decide the product to purchase, often their research lends to reviews from other proclaimed consumers of these same products. This reliance of peer product reviews on the Internet begs to ask what degree of truthfulness do the product raters provide to the consumer, and how does the consumer validate the reviews. The focus of this paper is to explore the degrees to which Internet consumers are aware of the shilling practice. In this exploration, an examination of what consumers believe about shill type peer product reviews in the Internet market space. The research is quasi-experimental and will define the framework for the proposed study to be conducted. The methodology is based on quantitative analysis and data will be collected through survey instrumentation. The conclusion is expected to provide perspective of consumers, regarding Internet product reviews, and how they classify or categorize responses from perceived customers about product interested in purchasing. This research is rich in consumer advocacy to help preserve the trust in Internet shopping and consumers awareness for their protection from misguided use of shill techniques on Internet products.
\end{abstract}

Keywords: Internet Shilling, Online Auctions, Product Reviews, Consumer Behavior and Consumer Trust

\section{INTRODUCTION}

\section{History of Shilling}

For centuries consumer have been the in the sights of crafty merchants with their alluring products and services. Some of the techniques used by these marketing innovators were to influence the decision making of the consumers to buy their products through indirect means of enhancing the value or desire for their product. This indirect method of drawing attention to their goods through other channels is known as shill. As information systems have developed using Internet products and services for commerce, this practice of shill has become a way for marketers to artificially create excitement and build up the essentialness of their products to the consumer. Webster's Dictionary defines "shill" as a transitive verb meaning "to act as a spokesperson or promoter" [14]. The term originated around auctions in Great Britain where individuals would act as decoys for the seller, falsely driving up bids on items to increase the price so that an actual bidder had to pay a higher price for the given item.

\section{The Shift to the Internet}

With the creation of online auction sites such as eBay, a new breed of shills came to life. These online shills would serve the same function as their real life cousins, bumping up bids on items to increase the sale price for the seller. In a new wrinkle, the online shills were sometimes the seller themselves, pushing the price up for themselves using a fake account. With online purchases in the billions, merchants are in a constant battle to draw the attention of consumers. With many consumers relying on the posted reviews of other products written by other consumers, some companies have adopted the tactic of Internet Shilling to foster false enthusiasm for their products in attempts to bolster sales. We propose to study this phenomenon to explore consumer recognizable attributes of shrill techniques used in the marketing of Internet products and services, and how this may affect consumer purchases of these products. 


\section{Issues in Information Systems \\ Volume 14, Issue 1, pp.311-314, 2013}

\section{Product Reviews Instead of "True” Shilling}

What started as a joke product review on www.amazon.com for the "Three Wolf Moon" T-shirt (Figure 1) spawned another evolution in the internet shill - fake product reviews. With global e-commerce reaching 1.8 trillion in 2012 and continuing to rise, consumers are relying on the reviews of other consumers for product knowledge and expertise to help them deem a product worthy of purchase [7].

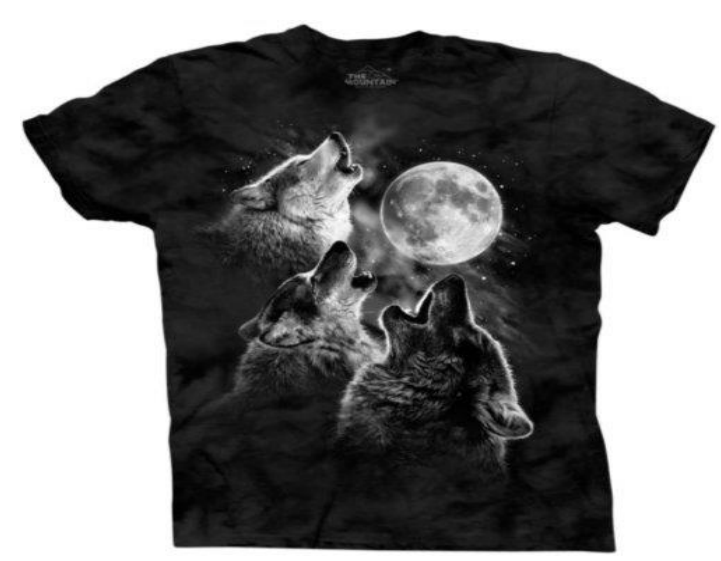

Figure 1. The original "Three Wolf Moon" T-shirt

Sales of the Three Wolf Moon shirt jumped 2,300\% after the false reviews were added to the listing. Comments included how the shirt fit a person's "girthy frame," and how one buyer was single-handedly able to stop crime in his city due to wearing the t-shirt [8].

Shortly after these humorous reviews went viral companies began recruiting individuals to post false product reviews on their company website in an attempt to boost sales the way Amazon received from the Three Wolf Moon. These companies were even offering stipends for each review posted to their site [17].

Considering the amount of business companies takes in from online sales of goods and merchandise, we ask the following questions: How does Internet Shilling affect consumer behavior? Does Internet Shilling affect consumer trust? Does awareness of the concept of Internet Shilling affect consumers' willingness to purchase products from certain vendors?

\section{LITERATURE REVIEW}

From the early 1900 s until today, shilling has had a considerable makeover. What was once a way to drive up auction prices and drum up enthusiasm in unwitting auction goers has now branched out into many areas, primarily on the Internet. Online auctions, consumer product or service reviews, and even comment/message/discussion boards are at the mercy of shills who attempt to influence the actions and opinions of unsuspecting web surfers [19].

Stealth marketing is a marketing concept that regards word of mouth endorsements as the most effective marketing strategy above all other traditional means $[10 ; 11 ; 12]$. Consumers are increasingly bombarded with traditional marketing and are becoming every cynical and impervious to such means. Stealth marketing subverts the traditional means by relying on creating "buzz" or positive word of mouth endorsements in a clandestine manner that leads the consumer to believe that the buzz or word-of-mouth was not the product of marketing. The use of Internet based word of mouth marketing is referred to as eWOM, this technique involves posting opinions, endorsements, and criticism on retailer, manufacture, portal and product review web sites $[12 ; 13 ; 9]$. The technique of eWOM has become an online version of shilling. 


\section{Issues in Information Systems \\ Volume 14, Issue 1, pp.311-314, 2013}

Internet shilling or eWOM, allows for marketers to self promote products or services covertly, with the intent of leading consumer to believe that the positive buzz was created by fellow consumers rather than marketers; leaning credence to the buzz. Although this form of marketing can allow for the subversion of consumers' cynicism and defenses, consumer trust is a factor that may prove difficult to mitigate for markers attempting to use eWOM campaigns. The asynchronous aspect of most online product reviews can lead to uncertainty and mistrust among consumers who are in search of honest and unbiased reviews to support their purchase decision making. Several theories that can be applied to deciphering the level of trust the average consumer has in regards to the eWOM they encounter include uncertainty reduction theory and regulatory focus theory $[2 ; 13]$.

Internet shilling has even morphed into several types of specific shilling with unique nomenclatures goals: astroturfing, sockpuppet, ballot stuffing and bad mouthing. Astroturfing is an act of creating an impression that there is a grassroots or underground support for an individual, product, or a governmental or corporate policy when there is no actual support. Astroturfing is usually found in the comments sections of online news articles, blogs, discussion boards or forums. Often astroturfing is funded and difficult to detect [15].

A sockpuppet refers to an individual who assumes a fake, online identity in order to drum up a positive option about their real identity, as well as other forms of deception. Ballot stuffing refers to the act of using an online vendors rating system to submit fake rating to either boost a vendors rating to influence individual to buy from that vendor, or damage a vendors rating to steer away consumers [19].

Similar to ballot stuffing, bad-mouthing is the act of spreading negative opinions about a merchant through ratings and comments. For example, a Pittsburgh, Pennsylvania-based contractor recently sued the online contractor review website Angie's List over what he claimed to be malicious and false claims by a poster on the site. The post claimed the contractor did not complete the job he was hired for, with the work completed being very suspect, at best. The contractor maintains that the individual posting these comments never entered into an agreement for him to perform any work on her property in the first place [18]. Additionally, a plumbing and heating company also located in Pittsburgh went as far as to file a lawsuit against the "John Does" posting false comments online, claiming that the false information was actually causing financial harm to the company.

Internet shilling can have a far retching effect on both the consumer and retailers or service providers. Those companies engaging in shilling or eWOM are at the mercy of a consumer's trust, cynicism or gullibility. Consumer or interested third parties can also engage in shilling and eWOM in order to hurt a business and steer consumers away from a particular product or service. This phenomenon can make it difficult for consumer to discriminate fact from fiction when reading reviews, but it also gives some power back to the consumers, as they are able to share their satisfaction or dissatisfaction of a product or service to world in the same manner as marketer use eWOM.

\section{PROPOSED RESEARCH}

We propose conducting exploratory survey research to study the phenomenon of Internet Shilling. With individuals from all walks of life able to purchase products on the Internet, any individual over the age of 18 is eligible to participate in this research. A pilot study was conducted during the summer of 2013, with the final survey distributed during the fall of 2013 and winter of 2014.

The survey instrument will be constructed to gauge a participant's online shopping habits, determining how much the participant relies on customer feedback and product reviews as a factor in their buying decisions. The participant will then be presented with a description of the concept of Internet Shilling. The participants will then be asked a second set of questions to determine if knowledge of shilling has an effect on their spending habits.

The survey will be conducted entirely online, with no restrictions on the amount of participants recruited. Participants will be recruited via e-mail or social media outlets. Participants will also be asked to pass on the survey information to other friends and family members via word-of-mouth.

The data collected will be analyzed to determine if there are any correlations between a consumer's purchase habits and their knowledge of the concept of Internet Shilling. 


\section{Issues in Information Systems \\ Volume 14, Issue 1, pp.311-314, 2013}

\section{CONCLUSIONS}

Recent studies have examined the concept of Internet Shilling in online auctions, but little research has been conducted on how Internet Shilling affects the online purchasing habits of the common consumer. We proposed to conduct a study examining this phenomenon to gain a better understanding of how awareness of the possibility of shilling in product reviews may or may not affect a consumers online purchasing decisions.

\section{REFERENCES}

1. Beranek, L., Tlusty, P., \& Remes, R. (2010). An Online Auction Trust Model for Based on the Contextual Information. University of South Bohemia, Department of Applied Mathematics and Informatics. Ceske Budejovice, Czech Republic: University of South Bohemia.

2. Berger CR, Calabrese RJ. (1975). Some explorations in initial interaction and beyond: Toward a developmental theory of interpersonal communication. Human Communication Research, 1(2): 99-112.

3. Berger CR, Gudykunst WB. (1991). Uncertainty and Communication. Ablex: Norwood, NJ; 21-66.

4. Bronner, F., \& Hoog, R. (2010). Consumer-generated versus marketer-generated websites in consumer decision making. International Journal of Market Research, 52(2), 231-248.

5. Chakraborty, I., \& Kosmopoulou, G. (2004). Auctions with shill bidding. Economic Theory, 24, $271-287$.

6. Dong, F., Shatz, S., \& Xu, H. (2010). Reasoning Under Uncertainty for Sill Detection in Online Auctions Using the Dempster-Shafer Theory. International Journal of Software Engineering and Knowledge Engineering, 20(7), 943-973.

7. Dusto, A. (2013). Global e-commerce tops $\$ 1$ trillion in 2012. Internet Retailer. Retrieved from http://www.internetretailer.com/2013/02/05/global-e-commerce-tops-1-trillion-2012

8. Emery, D. (2009, May 21). Joke review boosts T-shirt sales. Retrieved May 6, 2013, from BBC News: http://news.bbc.co.uk/2/hi/technology/8061031.stm

9. Hennig-Thurau, T., Gwinner, K., Walsh, G. \& Gremler, D. (2004). Electronic word-of mouth via consumer-opinion platforms: what motivates consumers to articulate themselves

10. on the Internet? Journal of Interactive Marketing, 18, 1, pp. 38-52.

11. Kaikati, A., Kaikati, J. (2004). Stealth marketing: how to reach consumers surreptitiously. California Management Review, 43 (4), 6-24.

12. Katz, E. (1957). The two-step flow of communication: an up-to-date report on a hypothesis. Public Opinion Quarterly, 21(1), 61-78.

13. Kwon, O., Sung, Y. (2012). Shifting selves and product reviews: how the effects of product reviews vary depending on the self-views and self-regulatory goals of consumers. International Journal of Electronic Commerce, 17 (1), 59-81.

14. Merriam-Webster. (2013). Shill. Retrieved May 6, 2013, from Merriam-Webster.com: http://www.merriam-webster.com/dictionary/shilling?show $=1 \& \mathrm{t}=1367850030$

15. Monbiot, G. (2011). Corporate-funded online 'astroturfing' is more advanced and more automated than you might think. Retrieved from http://www.alternet.org/story/150049/corporate-

funded_online_astroturfing'_is_more_advanced_and_more_automated_than_you_might_think

16. Osdol, $\bar{P}$. (2013). Company sues to reveal identities of online critics. WTAE-TV. Retrieved from http://www.wtae.com/news/local/investigations/company-sues-to-reveal-identities-of-online-critics//12023024/19972816/-/fckpyh/-/index.html on June 27, 2013.

17. Streitfeld, D. (2012) For $\$ 2$ a star, an online retailer gets 5-start product reviews. New York Times. Retrieved from https://www.nytimes.com/2012/01/27/technology/for-2-a-star-a-retailer-gets-5-starreviews.html

18. Ward, P. R. (2012, September 3). Construction company owner sues over woman's posting on Angie's List. Retrieved April 30, 2013, from Pittsburgh Post-Gazette: http://www.postgazette.com/stories/business/legal/construction-company-owner-sues-over-womans-posting-on-angies-list651654/

19. Wu, G., Greene, D., Smyth, B. \& Cunningham, P. (2010) Distortion as a validation criterion in the identification of suspicious reviews. University of Dublin Technical Report. 